\title{
INTRA-PARTY DEMOCRACY AND THE INCLUSION OF WOMEN
}

\author{
By \\ Bookie Monica Kethusegile-Juru \\ Bookie Monica Kethusegile-Juru is Technical Advisor (Gender) to the SADC Secretariat, \\ Private Bag 0095 Gaborone, Botswana Tel: +267 395.1863; Fax: +267 397.2848; e-mail: bkethusegile@sadc.int
}

\section{INTRODUCTION}

The inclusion of women in decision-making is a fundamental human right and an issue of social justice. There can be no democracy where 'decisions about changing the lives of people are taken without the participation of more than half of the very lives that have to be changed. It cannot be participatory democracy when decisions are taken by some on behalf of others' (Mtintso 1997). Further, it has been argued that the participation of women in leadership positions has brought about 'another perspective' and resulted in increased focus, attention and allocation of resources to life quality issues such as health and education. The participation of women has been credited with bringing about a qualitative transformation of institutions, laws and policies (Molokomme 2001a).

As Zofia Kuratowska, Deputy Speaker of the Polish Senate, noted 'nobody with common sense can doubt that the participation of women in the political decision-making process should be comparable to [that of] men'.

With that as background, this paper explores the extent to which intra-party democracy allows for the inclusion of women in electoral politics (Molokomme 2001b). There is no doubt about the political commitment of SADC member states at regional level to the attainment of gender parity in politics and decision-making, and indeed in all other spheres of life.

In the light of this expressed commitment, I explore the performance or practice of SADC member states in the representation of women in political decision-making positions and the trends that have emerged in methods of facilitating the entry of a critical mass of women into political leadership.

Finally, I reflect on the lessons that the DRC can learn from these experiences and their implications for a future in which gender parity will become the norm in SADC political systems.

\section{The COMmitment}

The commitment of SADC member states to gender parity in politics and decisionmaking has been made at the highest levels. 
Regionally, the Declaration on Gender and Development, signed by SADC heads of state or government in September 1997, commits SADC countries to:

ensuring the equal representation of women and men in the decisionmaking of member states and SADC structures at all levels, and the achievement of at least a thirty per cent target of women in political and decision-making structures by the year 2005 .

The Plan of Action for Gender in SADC that was approved by the Council of Ministers in September 1998 identifies the achievement of this target as one of its six objectives. In order to achieve the target, a Regional Programme of Action on Women in Politics and Decision-making was adopted by SADC Gender Ministers in June 1999, and is now being implemented (SADC Gender Unit 1999).

On receiving a progress report on the implementation of the Declaration, SADC heads of state or government at their summit in Maputo in August 1999 further committed themselves to adopting special measures, such as constitutional and/ or legislated quotas and nominations of women, to ensure the attainment of agreed targets.

\section{The Roles of Women AND Men \\ In Politics and Decision-Making In SADC}

The following statistics, showing the numbers of women in SADC parliaments and Cabinets, demonstrate how SADC countries are performing against expressed commitments.

The situation is summarised in Tables 1 to 3 and in figures 1 to 3 .

Figure 1

Percentage of Women in Parliament 1999 and 2002

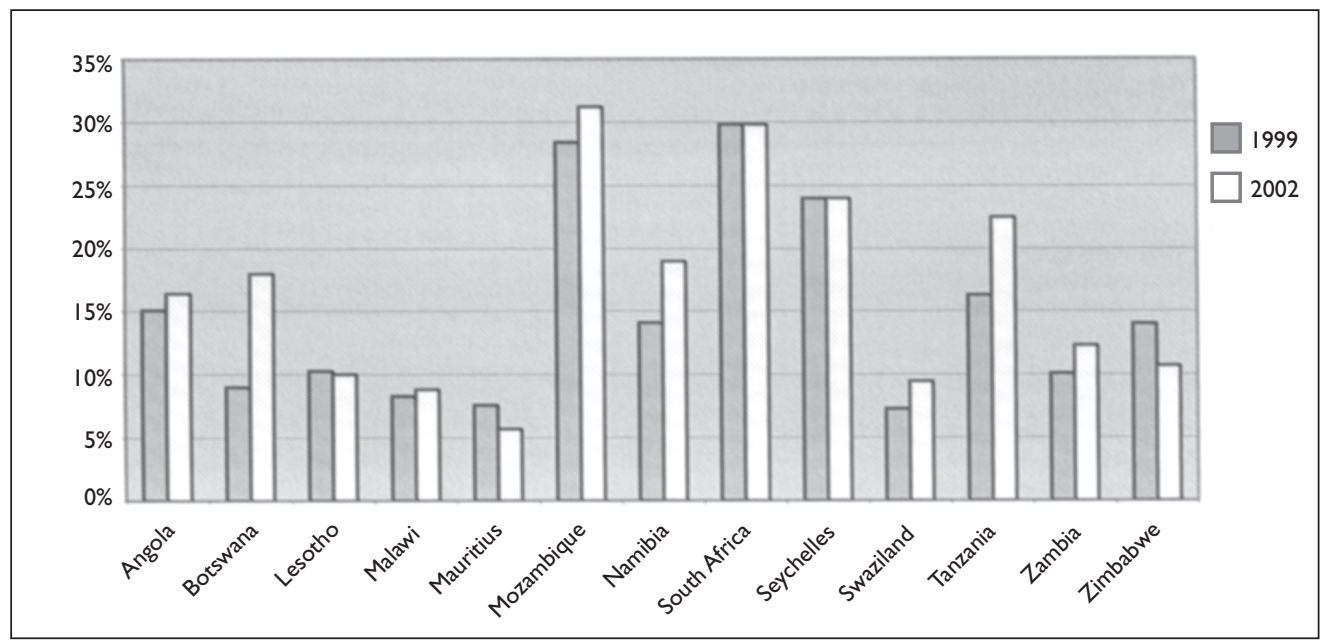

Source: SADC Secretariat 


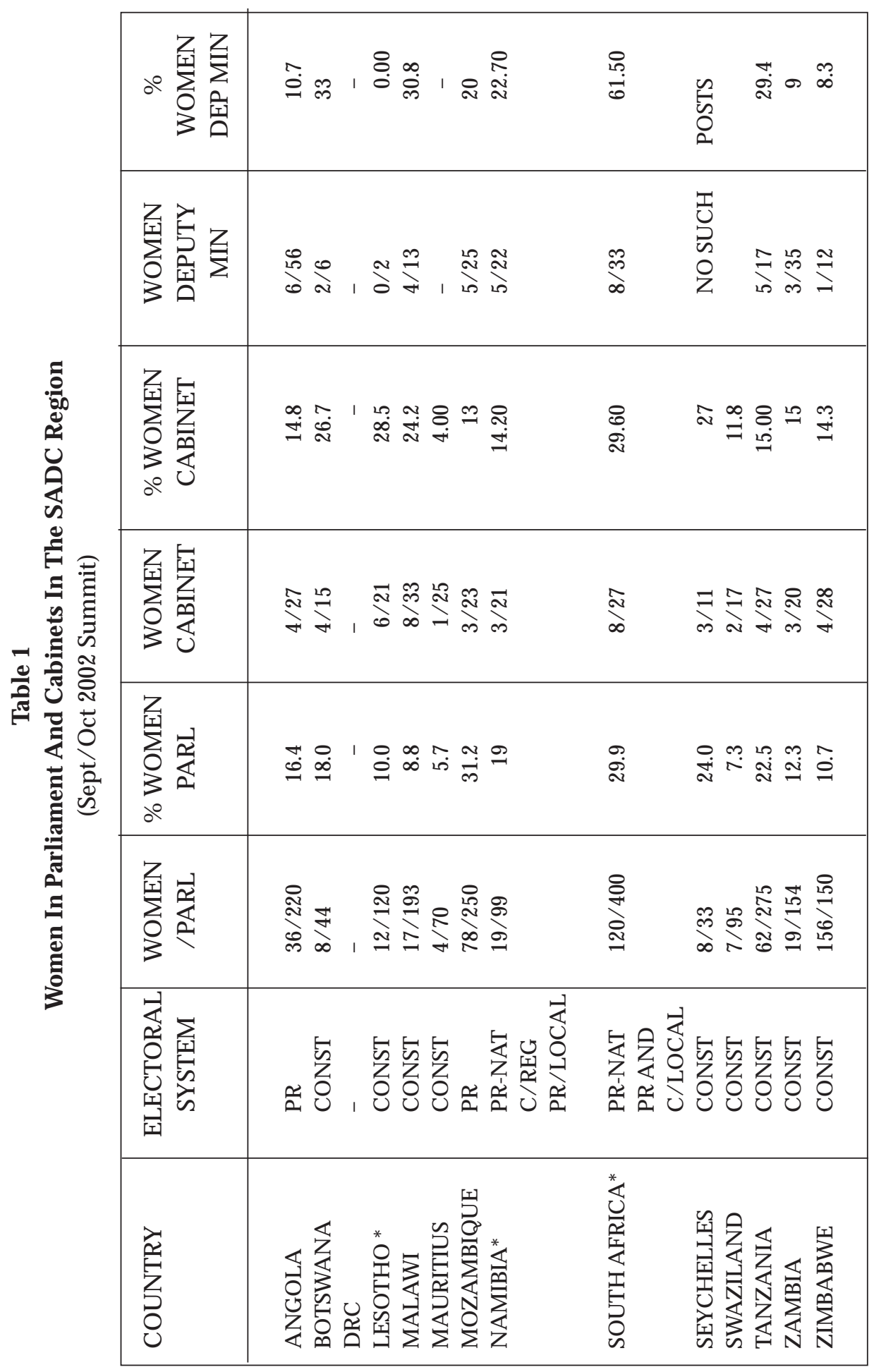


Figure 2

Percentage of Women in Cabinet 2001 and 2002

(Excludes Deputy and Assistant Ministers)

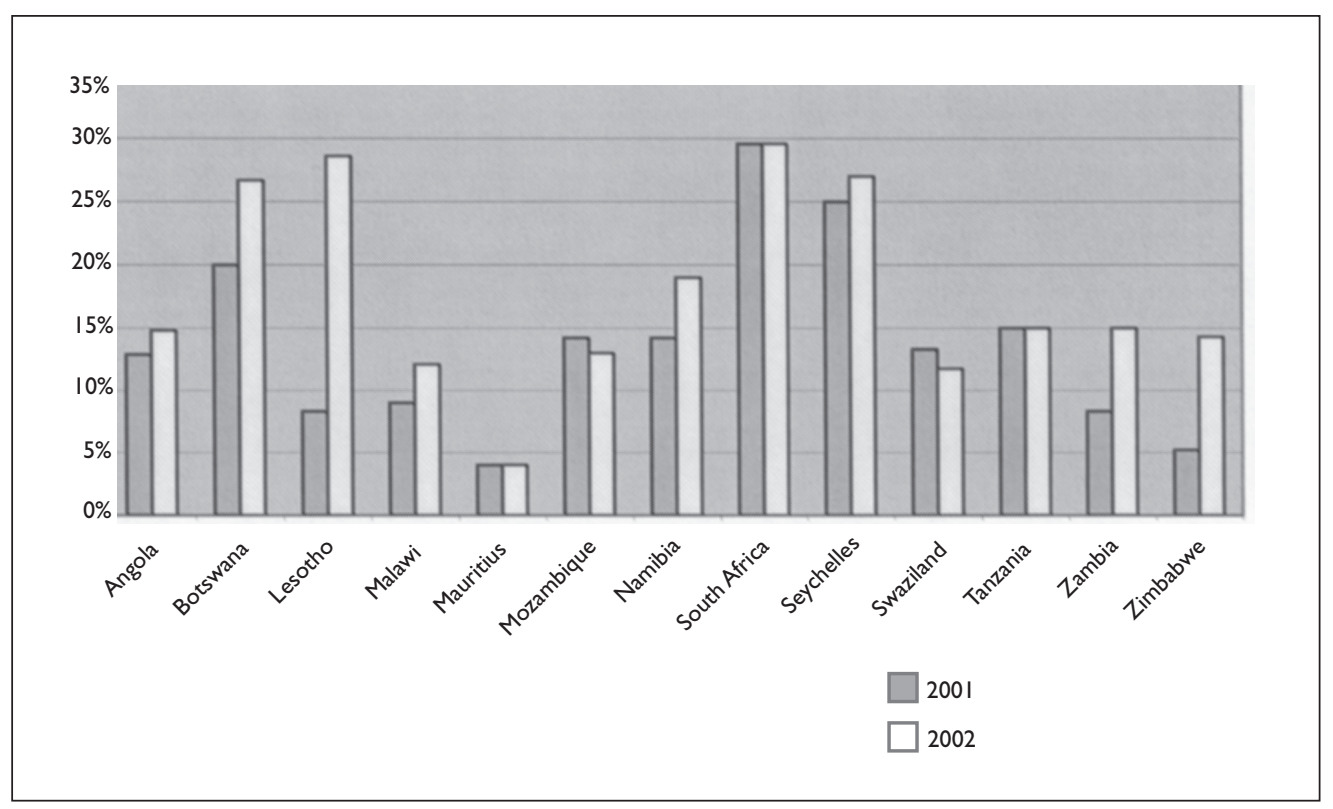

Source: SADC Secretariat

Figure 3

Percentage of Women in Parliament and Cabinet 2002

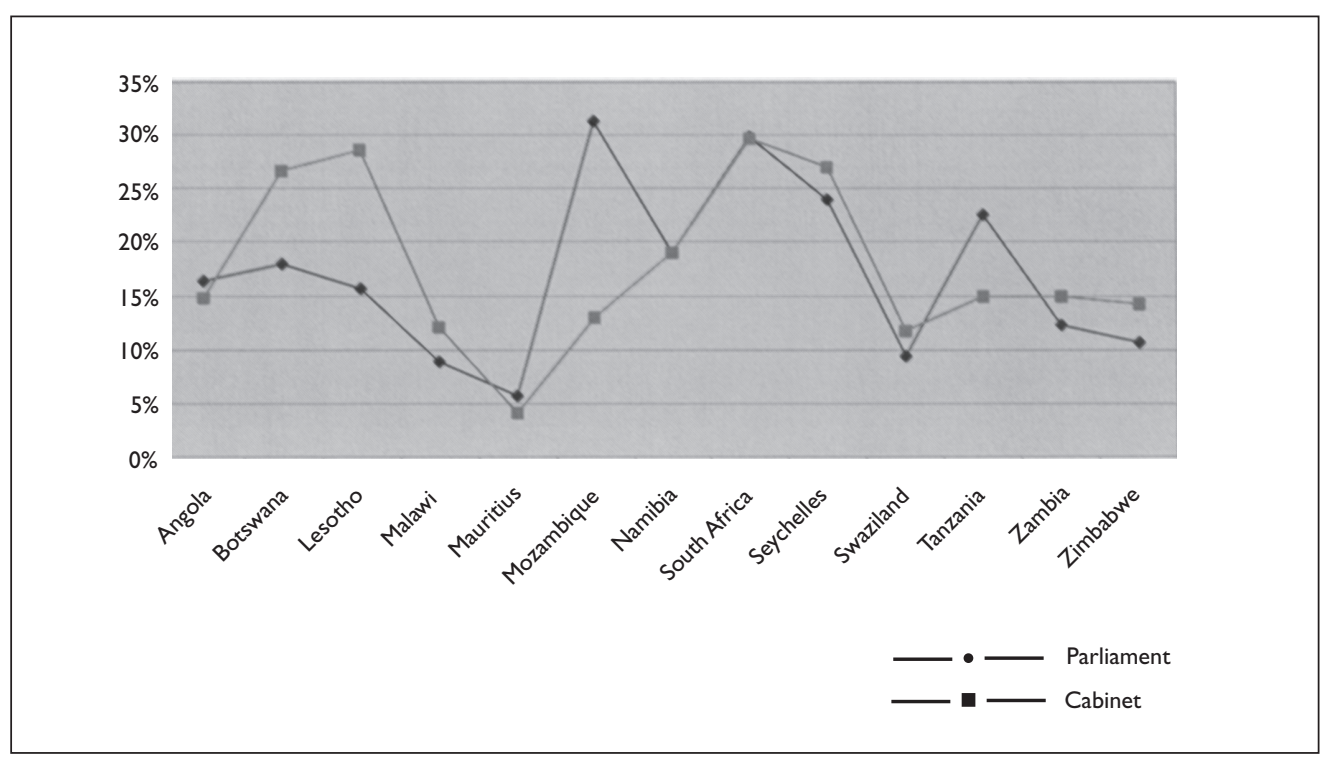

Source: SADC Secretariat 
Table 2

Analysis of Representation of women in SADC Parliaments

\begin{tabular}{|c|c|c|c|c|c|c|}
\hline COUNTRY & $\begin{array}{l}\text { ELECTORAL } \\
\text { SYSTEM }\end{array}$ & $\begin{array}{c}\text { NEXT } \\
\text { GENERAL } \\
\text { ELECTION }\end{array}$ & $\begin{array}{r}\text { WOMEN } \\
\text { IN } \\
\text { PARLIAI }\end{array}$ & $\begin{array}{l}\text { J/MEN } \\
\text { J } \\
\text { MENT }\end{array}$ & $\begin{array}{c}2005 \\
\text { TARGET }\end{array}$ & $\begin{array}{l}\text { ADDITIONAL } \\
\text { NO OF WOMEN } \\
\text { REQUIRED }\end{array}$ \\
\hline ANGOLA & PR & Not Known & $36 / 220$ & $(16.4 \%)$ & 66 & 30 \\
\hline BOTSWANA & CONST & 2004 & $8 / 44$ & $(18.0 \%)$ & 13 & 5 \\
\hline LESOTHO & CONST & 2002 & $12 / 120$ & $(10 \%)$ & 36 & 24 \\
\hline MALAWI & CONST & 2004 & $17 / 193$ & $(8.8 \%)$ & 58 & 41 \\
\hline MAURITIUS & CONST & 2005 & $4 / 70$ & $(5.7 \%)$ & 21 & 17 \\
\hline MOZAMBIQUE & PR & 2004 & $78 / 250$ & $(31.2 \%)$ & 75 & -3 \\
\hline NAMIBIA & $\begin{array}{l}\text { Pr-nat/ } \\
\text { C/Reg } \\
\text { PR/local }\end{array}$ & 2004 & $19 / 99$ & $(19 \%)$ & 30 & 11 \\
\hline S. AFRICA & $\begin{array}{l}\mathrm{PR} / \mathrm{Nat} \\
\mathrm{PR} \text { and } \\
\mathrm{C} / \text { local }\end{array}$ & 2004 & $119 / 400$ & $(29.8 \%)$ & 120 & 1 \\
\hline SEYCHELLES & CONST & 2004 & $8 / 34$ & $(23.5 \%)$ & 10 & 2 \\
\hline SWAZILAND & CONST & 2003 & 9/95 & $(7.3 \%)$ & 28 & 19 \\
\hline TANZANIA & CONST & 2005 & $62 / 275$ & $(22.5 \%)$ & 83 & 21 \\
\hline ZAMBIA & CONST & 2001 & $19 / 154$ & $(12.3 \%)$ & 46 & 27 \\
\hline ZIMBABWE & CONST & 2005 & $16 / 150$ & $(10.7 \%)$ & 45 & 29 \\
\hline
\end{tabular}

Source: SADC Secretariat

The figures as at February 2001 reveal the following general trends:

\section{Parliament}

- The average percentage of women in parliaments in the region (excluding the DRC, for which figures were not available) is about 17 per cent.

- South Africa leads the region, with the highest number of women in Parliament (31.3\%), followed by Mozambique (31.2\%). Both countries have passed the 30 percent minimum target. Seychelles has reached 24 per cent and Tanzania 22.5 per cent.

- Eight SADC countries have 15 per cent or higher representation - that is, more than half the desirable figure. In addition to those cited above, they are Botswana (18\%); Namibia (18\%),Angola (15.1\%) and Zambia (15\%).

- Mauritius, at 5.9 per cent, is furthest from reaching the target; followed by Malawi (8.3\%); Swaziland (9.47\%), Zimbabwe and Lesotho (10\%). Representation of women in Zimbabwe and Mauritius dropped after their elections in 2000. 
Table 3

Analysis of Representation of women in SADC Cabinets

\begin{tabular}{|c|c|c|c|c|c|c|}
\hline COUNTRY & $\begin{array}{l}\text { ELECTORAL } \\
\text { SYSTEM }\end{array}$ & $\begin{array}{c}\text { NEXT } \\
\text { GENERAL } \\
\text { ELECTION }\end{array}$ & & $\begin{array}{l}\text { N/MEN } \\
\text { N } \\
\text { AMENT }\end{array}$ & $\begin{array}{c}2005 \\
\text { TARGET }\end{array}$ & $\begin{array}{l}\text { ADDITIONAL } \\
\text { NO OF WOMEN } \\
\text { REQUIRED }\end{array}$ \\
\hline ANGOLA & PR & Not Known & $4 / 27$ & $(14.8 \%)$ & 8 & 4 \\
\hline BOTSWANA & CONST & 2004 & $4 / 15$ & $(26.7 \%)$ & 5 & 1 \\
\hline LESOTHO & CONST & 2002 & $6 / 21$ & $(28.5 \%)$ & 7 & 1 \\
\hline MALAWI & CONST & 2004 & $4 / 33$ & $(9.0 \%)$ & 10 & 6 \\
\hline MAURITIUS & CONST & 2005 & $1 / 25$ & $(4.0 \%)$ & 8 & 7 \\
\hline MOZAMBIQUE & PR & 2004 & $3 / 23$ & $(13 \%)$ & 7 & 4 \\
\hline NAMIBIA & $\begin{array}{l}\text { Pr-nat/ } \\
\text { C/Reg } \\
\text { PR/local }\end{array}$ & 2004 & $3 / 21$ & $(14.2 \%)$ & 6 & 3 \\
\hline S. AFRICA & $\begin{array}{l}\text { PR/Nat } \\
\text { PR and C/ } \\
\text { local }\end{array}$ & 2004 & $8 / 27$ & $(29.6 \%)$ & 8 & 0 \\
\hline SEYCHELLES & CONST & 2004 & $3 / 11$ & $(27 \%)$ & 4 & 1 \\
\hline SWAZILAND & CONST & 2003 & $2 / 17$ & $(11.8 \%)$ & 5 & 3 \\
\hline TANZANIA & CONST & 2005 & $4 / 27$ & $(15.0 \%)$ & 8 & 4 \\
\hline ZAMBIA & CONST & 2001 & $3 / 20$ & $(15 \%)$ & 6 & 3 \\
\hline ZIMBABWE & CONST & 2005 & $4 / 28$ & $(14.3 \%)$ & 8 & 4 \\
\hline
\end{tabular}

Source: SADC Secretariat

\section{Cabinet}

- The average percentage of women in Cabinets in the region (excluding the DRC, for which no figures were available) is 17.4 per cent. This figure does not include deputy and assistant ministers.

- Again, South Africa, with 33.3 per cent, has exceeded the 30 per cent minimum target, followed by Lesotho (28.5\%), Botswana (27\%) and Seychelles (23 per cent). In South Africa 57.1 per cent of deputy ministers are women, in Botswana 33 per cent, in Tanzania 29 per cent and in Mozambique 27.7\%.

- Tanzania (15\% ministers and $29 \%$ deputy ministers) and Zimbabwe (16\%) are just over the halfway mark while Angola, Mozambique, Namibia and Swaziland, are close to it. Swaziland (11.7\%), Malawi (9\%) and Mauritius $(4 \%)$ have the lowest representation of women in the Cabinet.

- In the seven countries for which data were available, an average of 26.9 per cent of deputy ministers were women, suggesting that women are generally better represented at that level. 


\section{Some Comparisons and Recent Trends}

- At 17 per cent, the proportion of women in parliament in SADC is considerably higher than the sub-Saharan Africa average of 9 per cent, the African average of 11 per cent and the global average of 13.4 per cent. The proportion is also higher than that for Europe (excluding the Nordic countries) and the Americas, where the figure is 15 per cent. Of the ten countries in the world with the highest representation of women in parliament, three of them - South Africa, Mozambique and Seychelle - are in Southern Africa (Lowe Morna 2000).

- Of the eight SADC countries that have held elections since 1999 the representation of women has only dropped in Mauritius (from 7.6\% to 5.9\%) and Zimbabwe (from $14 \%$ to $10 \%$ ). In the case of Botswana, the figure doubled from 9 to 18 per cent.

- There has been a positive tendency in the region in these years for women to be appointed to ministerial portfolios that have traditionally been considered the domain of men.

Although these figures should make the SADC region proud of its achievements, the relatively favourable averages should be judged against the performance of individual countries and the sustainability of the gains made. The figures in more than half the SADC member states are still under 15 per cent - far below the projected 30 per cent target. Moreover, those countries that are doing well in one area, such as parliament, are not necessarily performing as well with respect to Cabinet and other levels of decision-making, such as local government and senior public service positions.

In Mozambique, for instance, fewer than 15 per cent of Cabinet ministers are women, despite the fact that it has the second highest number of female parliamentarians and, in Namibia, which is low on the list of women parliamentary representatives and Cabinet ministers, an impressive 43 per cent of those in local government are women.

A notable exception is Seychelles, which, in addition to satisfactory percentages in parliament and the Cabinet has a record 60 per cent of women in local government.

These trends naturally raise the question of what the countries that are performing well with respect to women's representation in political positions have done to attain these impressive figures. To what extent have intra-party democracy and various election systems facilitated or hindered the inclusion and maximum participation of all social groups, especially marginalised groups such as women? What measures are necessary to ensure that the gains are not reversed?

\section{The Role of Electoral Systems}

Although in-depth research has not been conducted in all countries, available evidence both from within SADC and from outside suggests that the choice of 
electoral system can contribute greatly to the achievement of gender equality in politics. This applies to electoral systems at various levels - the overall system at national, provincial, and regional level, as well as the procedures and systems within parties, such as primary elections. The latter are often ignored, but they certainly have a major impact on the representation of women in political leadership.

\section{Intra-Party Electoral Systems and Procedures}

The process of selecting candidates within political parties is just as important perhaps even more important - to inclusivity than the type of electoral system at national level (Molokomme 1999). Political parties have their own internal procedures for selecting those who will stand for them, and someone who seeks political office and does not survive the selection process at the party level cannot stand as that party's candidate. It is therefore important that selection procedures within parties be inclusive, transparent and democratic.

Before the 1994 democratic elections in South Africa women constituted 2.7 per cent of Members of Parliament. Because the ANC provides for a 30 per cent quota for women 27 per cent of National Assembly seats in the 1994 elections went to women. The decisive role of the ANC quota, together with the proportional representation system, directly increased the representation of women (Mtintso 1999). In the 1999 elections women's representation further improved to reach the present figure of close to 30 per cent. The appointment of eight women ministers and eight deputy ministers improved the position of women in the Cabinet.

Similarly, a major victory for feminists in Norway was the acceptance of gender quotas - a controversial move. Quotas were initially accepted within the Labour Party and were later introduced by the centre parties. The Labour Party then introduced gender quotas in government. Thus in 1996, 40 per cent of the MPs in Norway were women, 45 per cent in the executive of government, 33 per cent in the councils of local municipalities and 40 per cent in regional councils.

As with the proportional representation system of the ANC, in Norway a list of candidates nominated by each party runs for several seats in every constituency. This system makes it far easier for women to be nominated and elected. It also provides an opportunity for broader recruitment and participation of women in party leadership positions. It is a 'rule' in Norway that every second name on the list of candidates should be that of a woman (Hilde Frafjord Johnson 1996).

In the SADC region, the fact that there are 31.2 per cent women in the Parliament of Mozambique is largely due to Frelimo's deliberate policy of including women. Out of a total of 129 Members of Parliament, Frelimo has 37.7 per cent, Renamo 13.4 per cent and UD 11.1 per cent.

In Namibia the representation of women increased significantly when the affirmative action law was applied in the first two local government elections. Now 43 per cent of local government seats are held by women. The affirmative action law was not applied in relation to regional decision-making positions or to 
parliamentary elections so women only occupy 3 per cent of regional positions and 19 per cent of parliamentary seats (Eunice lipinge 1997).

Unfortunately, in most cases procedures are, at best, gender blind, and at worst not sufficiently transparent and democratic. Generally, they have not been conducive to the election of women and, in some cases, they have contributed to the marginalisation of women candidates within parties. The option of going independent is the only other route, but this has not proved feasible.

It appears that the most common method of selecting internal party candidates, especially in constituency-based systems, is through primary elections, of which there are at least two forms - direct and indirect. In the direct system all members of a political party who qualify can vote for the candidate of their choice in the primary election. In the indirect system, which is more common, voters select a smaller number of representatives to vote on their behalf in the primaries. An example of this is the electoral college system. The latter system has been criticised on the basis that it is more susceptible to manipulation, especially by wealthy and influential members of the party. It is often argued that it is easier to buy the votes of or influence the few people in the electoral college than to do so in the case of a body of voters. In many cases where this system has been used it has tended to return the same powerful candidates or groups of people to power (See Somolekae 1998).

In view of the gender imbalances within parties and society generally, this system is not conducive to the election of marginalised groups such as women. In fact, in the case of Botswana, women politicians have identified the electoral college system as one of the stumbling blocks to their standing for office.

Direct elections are more likely to benefit women candidates because they tend to do most of the organising, fundraising and campaigning for their parties at the grassroots level, and are better known and appreciated by their own constituents at this level.

\section{TYPeS OF Electoral SYSTEM}

\section{Proportional Representation (PR) versus Constituency-Based Systems}

Writing on the situation in the Commonwealth, Lowe Morna (1996) observes that there is overwhelming evidence to suggest that women stand a better chance of being elected under the PR system than under a constituency-based system. The reason for this, she argues, is because in the former case 'candidates focus on the party and its policies, rather than on a particular individual. This works in favour of women - at least in getting their foot in the door - because of the in-built prejudices against women.'

The experience of SADC countries supports the observation globally that the proportional representation and list system is more conducive to the representation of women than the constituency based system. The case of Norway is an example of this. 
Of the thirteen SADC countries represented in Table 1, six have constituencybased electoral systems. Four of these - Mozambique, Namibia, South Africa and Angola - have proportional representation systems, except at the local level in South Africa (in which there is a combination of the PR and constituency-based systems) and at the regional level in Namibia (where elections are constituency based). Seychelles has a mixed PR and constituency-based system. Tanzania has a constituency-based system with 20 per cent of seats reserved by the Constitution for women and contested on a PR basis.

In other words, two of the three countries in SADC with the highest representation of women in parliament (South Africa and Mozambique) have proportional representation systems. The third top performer, Seychelles, has a mixed system. This shows a definite correlation between the use of PR, either in full or in part, and increased representation of women in political leadership positions.

Writing on the 1994 elections in South Africa, Mtintso (1999) observes that:

The 1994 national and provincial elections were run wholly on a proportional representation basis. The advantage of the proportional representation system for women is illustrated by the contrast between the national/provincial and local government elections. In the seats contested on the basis of proportional representation, women won 27.9 per cent of the seats. In the ward or constituency based seats, women won only 10.84 per cent of the seats. This gave an overall average of 19 per cent of the seats in local government being won by women.

\section{Quotas and Special Measures}

The PR system on its own is not an absolute guarantee of increased representation of women. According to Lowe Morna (2000), the chance of women getting elected is even higher when the PR system is combined with a legislated or party-based quota. As is shown in the following (edited) extract from her paper, there are four possible combinations of quotas and electoral systems.

\section{The Voluntary Party Quota, combined with the Proportional Representation (PR) System}

Examples of this are found in South Africa and Mozambique, and it is no coincidence that these are the two countries in SADC with the highest representation of women in parliament. The two ruling parties, the ANC and Frelimo, have voluntarily adopted 30 per cent quotas. Because they are the majority parties, this system has ensured levels of representation by women of close to thirty per cent. The disadvantage of this system is that it is reliant on the ruling parties winning 
substantial majorities. In other words, unless every party contesting an election has a 30 per cent quota, there is no guarantee that the 'critical mass' of 30 per cent will be achieved.

\section{The Legislated Quota, Combined with the Proportional Representation} System

An example of this is the local government elections in Namibia. Because the quota was legislated, as opposed to being voluntarily adopted by one or other party, the 30 per cent representation of women was guaranteed. However, because some parties fielded more than the statutory minimum, the overall outcome was 41 per cent. This suggests that the legislated quota and PR system is the most powerful combination for achieving gender parity in politics - the ultimate objective.

The Legislated or Constitutional Quota in the Constituency-based System The example of this in Southern Africa is in Tanzania, whose Constitution stipulates that at least 20 per cent of the 283 members of parliament must be women. In other words, 47 seats are reserved for women. With the eight seats that women contested directly and won, this has given women in Tanzania an overall representation of 16.4 per cent in parliament. Clearly, the quota has boosted the level of representation by women in Tanzania.

\section{The Voluntary Party Quota Combined with the Constituency-based System}

An example of this is that of the Labour Party in the United Kingdom, which, through its commitment to fielding women candidates, managed to increase substantially the representation of women .

On the other hand, in Botswana, which has a constituency system, two opposition parties (the Botswana Congress Party and Botswana National Front) had thirty per cent quotas for women for the 1999 elections. However, the parties did not actively ensure that their quotas were met - they did not review their procedures to enhance access by women, nor did they head hunt or encourage women to stand for the primary elections. As a result, the parties fielded very few women in the national parliamentary elections.

By contrast, the ruling Botswana Democratic Party (which does not have a quota for women, but yielded to pressure from women in the party and from women's organisations) fielded more women, many of whom were elected and are now in parliament and the Cabinet. This example shows that while quotas are indeed useful, it is vital that political parties act to ensure that their structures and culture enable and encourage women to stand for elected office.

In addition to quotas, the electoral systems of many countries (Zimbabwe, Botswana and Swaziland are examples) allow the head of state to make some appointments to parliament. Indeed, of the eight women in the Swazi parliament, only two were elected. The King appointed the other six. Similarly in Botswana, 
two of the eight women in Parliament are specially nominated - a practice that has been in place for some time.

\section{CONCLUSION}

Internal political party electoral systems and procedures, especially for primary elections, can play a major role in promoting the election of women to positions of power. Related to this is the importance of demonstrated commitment and action on the part of political parties to implementing agreed measures such as quotas. This requires a fundamental transformation of party structures, rules and institutional cultures to make them more encouraging to women candidates. Such a culture must be internalised by party members, who should feel a sense of ownership of the process rather than see it in narrow terms as the agenda and responsibility of the women members of the party.

A democratic party is one which believes in and operates on principles of social justice, gender equality and equity; embraces the principle that women's rights are human rights; allows women and men to have equal rights and exercise their political and civic rights and provides structures to enable both women and men to stand for elections. It should also nominate candidates on merit and empower women members to participate effectively in the mainstream activities of the party, without fear of intimidation.

Democratic processes and procedures within a party should bridge the gaps between the various groups so that all, regardless of sex, class or race, are able to participate effectively and efficiently in party activities and programmes.

In a democratic institution any member can stand for election for any decisionmaking position at any level, and all can exercise their right to vote.

Intra-party democracy and inclusivity needs to be sustainable, and this requires a political party to have in place structures and systems that will ensure that all groups are catered for at all times. Resources need to be invested to ensure that the systems and processes are sustained.

There is no doubt that the choice of electoral system has a direct impact on access by women to elected positions. Available evidence from SADC countries shows that the PR system is more likely than the constituency-based system to deliver more women candidates. This conclusion has wider implications, in view of the ongoing debates in some SADC countries about changing from the PR system to a mixed system. It is important that the impact of such a change on women's representation be taken into account fully in these debates. In countries such as South Africa, which has the highest number of women in Parliament of the SADC countries, changes in the electoral system for the 2004 elections could erode the gains already made, and retard the achievement of the 30 per cent target by 2005 .

It is also clear that the PR system on its own is not a sufficient guarantee of a critical mass of women in elected positions - it needs to be supplemented by a quota system, preferably one that is either constitutional or legislated, if it is to 
achieve the desired result. While voluntary, party-based systems have worked in countries like South Africa, Mozambique and Namibia (at local government level), they are dependent upon the relevant parties winning large majorities. This justifies the call for explicit constitutional and legislative provisions for gender equality in SADC countries. In addition, legislative provisions for mandatory quotas may be required as a temporary measure until gender parity is achieved.

There is no doubt that while the choice of electoral system plays a major role in the participation of marginalised groups such as women in elected offices, other variables are also at play, which have not been raised in this short paper. Gender biases and stereotypes that do not encourage women to enter politics remain pervasive at all levels of society in SADC member states, and governments and political parties should play a leading role in social engineering. It is therefore the responsibility of all stakeholders in civil society, as well as researchers, independent electoral commissioners and academics, to consistently raise the issue of gender equality in leadership politics as part of their discourse on good governance and human rights.

\section{- REFÉRENCES - -}

Frafjord Johnson, H. 1996. In Women in Decision-Making: Empowerment for Action. AWEPA.

lipinge, E. et al. Forthcoming. The Status of Women in Politics and Decision-making in Namibia, 2000-2001. Report commissioned by the SADC Secretariat.

Lowe Morna, C. 1996. 'Strategies for Increasing Women's Participation in Politics'. Paper presented to the Fifth Meeting of Commonwealth Ministers Responsible for Women's Affairs.

- 2000. 'Women's Political Participation in SADC'. Paper presented at the International IDEA Conference: 'Towards Sustainable Democratic Institutions in Southern Africa'. Gaborone, Botswana, May.

Molokomme, A. 1999. 'Gender Equality in SADC: A Democratic Imperative'. Paper Presented to the SADC-EU Conference on 'Strengthening and Consolidating Democracy in SADC Through the Electoral Process'. Gaborone, Botswana.

- . 2000a. 'Gender and Democracy in SADC: A Regional Case Study'. Paper presented to the Commonwealth Workshop on 'Gender and Democracy'. Windhoek, Namibia, 9-11 February.

2000b. 'Obligations and Timelines Under the 1997 SADC Declaration on Gender and Development and the 1999 Programme of Action on Women in Politics and Decision-making'. Paper presented to the seminar on 'Parliamentary Action on the Beijing Plus Five Review Process', Gaborone, April.

2001a. 'Representation of Women and Men in Politics and Decision-making Positions in SADC. 
2001b. 'Building Inclusiveness in SADC's Democratic Systems: The Case of Women's Representation in Leadership Positions'. Report of the SADC Elections Forum. Johannesburg: EISA

Mtintso, T. 1997. 'Into the Future: Gender and SADC'. Keynote Address.

- 1999a. 'Women in Politics and Decision-making: A Conceptual Framework'. Paper presented at the Conference on 'Women in Politics and Decisionmaking', Gaborone, March.

1999b. 'A Voluntary Party-Based Quota in a List System'. Paper presented at the Conference on 'Women in Politics and Decision-making', Gaborone, March 1999.

SADC, FEF, UNDP and Botswana Caucus for Women in Politics. 1999. Beyond 30 per cent in 2005: Women in Politics and Decision-making in SADC. Report of a conference held in Gaborone, Botswana, 28 March to 1 April.

SADC Gender Unit. 1999. Regional Programme of Action for Women in Politics and Decision-Making in SADC: Beyond 30\% in 2005.

Somolekae, G. 1998. 'The Various Systems of Party Primary Elections in Botswana'. Paper presented to the National Conference on 'Women Preparing to Stand for the Primaries in Botswana', Emang Basadi, Gaborone. 